\title{
EVALUATION OF DIRECT ACTING ANTIVIRAL AGENTS IN THE TREATMENT OF PATIENTS WITH CHRONIC HEPATITIS C INFECTION IN ALEXANDRIA.
}

\author{
Marwa M. Fekry ${ }^{(1)}$, Mona H. Hashish ${ }^{(1)}$, Heba S. Selim ${ }^{(1)}$, Mie A. Ragab ${ }^{(2)}$ \\ 1) Department of Microbiology, High Institute of Public Health, Alexandria University, Alexandria, Egypt. \\ 2) Alexandria Fever Hospital, Ministry of Health, Alexandria, Egypt.
}

\begin{abstract}
:
Background Hepatitis C virus (HCV) infection in Egypt is the highest in the world. The goals of HCV treatment are to eliminate the infection and reducing its consequences. With the highly effective oral antiviral regimens for chronic hepatitis C (CHC), most cases can reach sustained virological response (SVR). Aim This study aimed to evaluate direct acting antivirals (DAAs) in HCV treatment among patients with CHC infection by investigating the SVR12.

Methods This cross-section study was carried out on 127 CHC patients receiving DDAs. They were subjected to quantitative determination of HCVRNA by RT-PCR at start of treatment and after 12 weeks from the end of the therapy to assess the SVR.

Results Among those patients, $126(99.2 \%)$ were responders meeting the criteria of SVR12, and only one patient $(0.8 \%)$ was non-responder. The latter was 58 years old female. She had high baseline HCV RNA level of $2.3 \times 106$ $\mathrm{IU} / \mathrm{ml}$, non-cirrhotic and had fatty liver. She was negative for HBsAg and HIV. The patient had experienced treatment failure in previous IFN-based therapeutic regimen. She received $\mathrm{SOF}+\mathrm{DAC}+\mathrm{RBV}$ regimen. There was a statistically significant decrease in ALT, AST and hemoglobin levels and a significant increase in total and direct bilirubin levels after treatment when compared with their levels before treatment.

Conclusion There was a high achievement of SVR12 indicating high effectiveness of DAAs treatment regimens.
\end{abstract}

Keywords: DDAs, SVR, CHC, HCV RNA, HCV.

\section{INTRODUCTION}

Infection with $\mathrm{HCV}$ is a major cause of chronic liver disease, ranging from minor changes to severe fibrosis and cirrhosis with or without HCC.[1] It affects up to 185 million people worldwide, therefore, its prevention and associated disease burden represents a major public health issue.[2] An estimated 71 million people (1\% of the world population) were living with chronic HCV infection in 2015 and an additional 1.75 million new infections occurred worldwide. [3].

HCV constitutes an epidemic in Egypt which is having approximately 10 -fold higher prevalence than other countries as it is estimated that about $10 \%$ of Egyptians are HCV positive.[4-6] Globally, HCV genotype 4 accounts for roughly $13 \%$ of all $\mathrm{HCV}$ infections.[7] In Egypt, over $90 \%$ of the infections have been reported to be $\mathrm{HCV}$ genotype 4.[8]

The goal of hepatitis $C$ treatment aims to eradicate $\mathrm{HCV}$ infection, thus reducing the risk of progression to HCV-related liver complications. The endpoint of HCV treatment is an SVR indicated by undetectable HCV RNA level 12 weeks or 24 weeks after treatment completion. SVR correlates strongly with a permanent clearance of the virus.[9].

The treatment of $\mathrm{CHC}$ has evolved over the years. Interferon (IFN) monotherapy was first used, then ribavirin (RBV) was added to IFN or to pegylated IFN (Peg-IFN).[9,10] The latter together with RBV was considered to be the standard therapy for CHC. SVR was obtained in nearly $50 \%$ of genotype 1 patients and $80 \%$ for genotype 2 and 3 patients after 48 and 24 weeks of therapy, respectively.[10,11] In Egypt, SVR rates exceeding $60 \%$ were reported when Peg-IFN and RBV combination therapy was used to treat $\mathrm{HCV}$ genotype 4 infected patients.[12] However, this regimen was associated with substantial limitations, including suboptimum response rates, large sideeffects, high treatment discontinuation rates, and prolonged treatment durations.[13]

During the last decade, DAAs were the point of research. These can inhibit the activity of several viral enzymes as NS3-4A serine protease, blocking HCV polyprotein processing. Among the DAAs, several drug families, such as 
nucleoside/nucleotide and non-nucleoside inhibitors of the RNA-dependent RNA polymerase and inhibitors of the NS5A viral protein can inhibit HCV replication. DAAs also have fewer side effects, shorter duration of treatment and some of them improve the SVR.[14, 15]

In November and December 2013, HCV NS3/4A protease inhibitor, simeprevir (SMV) (Olysio), and HCV NS5B polymerase inhibitor sofosbuvir (SOF) (Sovaldi) were approved by the Food and Drug Administration. SOF was considered part of a combination antiviral regimen for treatment of $\mathrm{CHC}$ infection genotypes 1, 2, 3, and 4 interrupting $\mathrm{HCV}$ replication. $(9,10)$ The choice of DAAs regimen varies according to $\mathrm{HCV}$ genotype, presence of viral mutations, drug availability, previous treatment and potential adverse effects. [15]

Since 2006, the Ministry of Health has implemented peg-IFN and RBV in Egypt through a national treatment program for patients with CHC infection.[16] Another strategy for managing those patients was launched later using larger fund from the World Health Organization and other national institutes.[17] Later, this plan called "The 2014-2018 Action Plan for Viral Hepatitis Prevention, Care and Treatment puts SOF as the main drug of treatment. The aim is to treat a large number of HCV infected cases with a high cost of treatment shared mainly between the Egyptian Ministry of Health and the Egyptian Health Insurance Organization. [18]

In a global study to estimate the prevalence of HCV by 2030, it was found that the morbidity and mortality associated with $\mathrm{HCV}$ can be dramatically reduced by raising the diagnosis and the number of people receiving higher efficacy treatment.[19] The objective of this study was to detect the SVR achieved through DAAs treatment by evaluating the level of HCV RNA among CHC patients before and 12 weeks after treatment.

\section{PATIENTS AND METHODS:}

This comparative cross-section study was carried out from November 2017 through April 2018 on patients infected with chronic HCV attending Alexandria Fever Hospital

\section{Sample size and Sampling technique}

- A sample size of 127 patients was the enough required sample to detect an effect size of 25 improvement in the primary outcome (SVR),[20] as statistically significant of $80 \%$ power and at a significance level of 0.05.[21] The sample size was calculated using GPower program (version 3.1.9.2).[22]

- The study was approved by the Ethics Committee of the High Institute of Public Health and Ethics Committee of the Egyptian Ministry of Health.

- All participants were asked to freely volunteer to the study and informed consents were gathered prior to their inclusion in the study protocol.

\section{The inclusion criteria:}

According to the treatment regimen adopted at Alexandria Fever Hospital, the patients enrolled in this study were adults, ( $\geq 18$ years), CHC confirmed by serum HCV-RNA level detected using an RT-PCR-based method and with renal function compatible with DAAs therapy.

The exclusion criteria:

HCV infected patients under the age of 18, patients who have hypersensitivity to treatment.

\section{Data collection methods and tools:- \\ 1) Full history taking:}

- A questionnaire sheet including demographic and clinical data was completed for every patient; as regards name, age, sex, residence, disease duration, medical history and previous anti-HCV therapy.

- Reviewing of the medical records of the patients to determine the HBV and HIV infection status.

\section{2) Clinical examination:}

- Careful clinical examination was performed to all patients under the study by internist of Alexandria Fever Hospital.

- Abdominal ultrasound was performed for each patient to diagnose cirrhosis.

- Patients eligible for treatment received one of the following regimens for 12 weeks:

- Daily SOF (400mg) + daily daclatasvir (DAC) (60mg).

- Daily SOF (400mg) + daily DAC (60mg) + RBV (1000 $\mathrm{mg}$ if $<75 \mathrm{~kg}$ or $1200 \mathrm{mg} \geq 75 \mathrm{~kg})$.

- Daily SOF (400mg) + daily SMV (150mg).

\section{3) Laboratory investigations:}

Patients included in the study were subjected to quantitative determination of serum HCV- RNA by RT-PCR to assess the SVR after 12 weeks from the end of therapy

\section{I) Blood sampling:}

Three $\mathrm{ml}$ of venous blood were drawn from each subject included in the study, under complete aseptic conditions; one $\mathrm{ml}$ in the tube containing EDTA to measure hemoglobin level and $2 \mathrm{ml}$ were allowed to clot for 1-2 hours at room temperature and serum was separated by centrifugation at $1000 \mathrm{rpm}$ for 20 minutes. Sera were distributed into aliquots to be used for assessment of ALT, AST, serum bilirubin levels and for molecular assay. [23,24]

\section{II) Determination of $\mathrm{HCV}$ viral load:}

Determination of active viral replication (viral load) was done by measuring serum HCV RNA levels using RT-PCR.

\section{Quantitative detection of HCV RNA by RT- PCR. [25] HCV RNA extraction}

RNA extraction was performed using QiagenQIAamp viral RNA mini spin protocol.

The amplification reaction was performed as follows: 
RNA amplification was performed using Qiagen kit (Artus, QS-RGQ(72) HCV PCR kit) RNA protocol with TaqMan assay reagents [25]

- RG master A (6 $\square 1)$

- RG master $\mathrm{B}(9 \square \mathrm{l})$

- $10 \mu \mathrm{l}$ of Qiagen extracted RNA were added to bring the reaction to a final volume of $25 \square 1$

- RT- PCR was performed with the Mx3000P TM (Stratagene) RT- PCR system.

- Software provided in the computer system connected to the apparatus allows real-time amplification plots to be viewed and to be analyzed during PCR run.

\section{Thermal profile:}

Amplification and detection of cDNA were carried out according to instruction of the kit manufacture as follows: Incubation at $50^{\circ} \mathrm{C}$ for $30 \mathrm{~min}$ to transcribe viral RNA to cDNA by RT. This was followed by AmpliTaq gold activation for $95^{\circ} \mathrm{C}$ for $10 \mathrm{~min}$, followed by 40 cycles of two PCR-step amplification, denaturation for $95^{\circ} \mathrm{C}$ for $15 \mathrm{sec}$, followed by annealing and extension at $60^{\circ} \mathrm{C}$ for $1 \mathrm{~min}, 72^{\circ}$ $\mathrm{C}$ for $30 \mathrm{~min}$, respectively with end point fluorescence detection.

\section{Statistical methodology}

Data were collected and entered to the computer using SPSS (Statistical Package for Social Science) program for statistical analysis version 21. [26] Data were entered as numerical or categorical, as appropriate. Data were described using minimum, maximum, mean, standard deviation and $95 \%$ CI of the mean. Categorical variables were described using frequency and percentage. Comparisons were carried out between two studied dependent normally distributed variables using paired t-test. [21]

\section{RESULTS}

In the present study, 127 chronic $\mathrm{HCV}$ patients received DAAs and were followed up for monitoring the SVR at 12 weeks after completing the therapy. The feedback from the patients on adverse drug effects showed that headache, fatigue, insomnia and nausea were commonly reported from most of them. From those patients, 126 (99.2\%) were responders meeting the criteria of SVR12, and only one patient $(0.8 \%)$ was non-responder. The latter was 58 years old female. She had high baseline HCV RNA level of $2.3 \times 106 \mathrm{IU} / \mathrm{ml}$, non-cirrhotic and had fatty liver. She was negative for HBsAg and HIV. The patient had experienced treatment failure in previous IFN-based therapeutic regimen. She received SOF + DAC + RBV regimen.

Table (1) summarizes the demographic and clinical data of the studied $127 \mathrm{CHC}$ patients. Their age ranged from 18 to 73 years with a mean of 48.98 years \pm 12.08 years. As regards sex; the number of males of the studied patients was 43 $(33.86 \%)$, and number of females was $84(66.14 \%)$. One hundred and twenty three patients $(96.85 \%)$ were treatment naive. None of the enrolled patients reported alcohol or intravenous drug intake. Hypertension, diabetes, cirrhosis and fatty liver were found in $60(47.24 \%), 45(35.43 \%), 20$ $(15.74 \%)$ and $70(55.11 \%)$, respectively. All patients were negative for HBV and HIV infections as well as HCC.

HCV RNA levels of the 127 chronic HCV patients before treatment are demonstrated in table (2) where they ranged from $1.3 \times 103$ to $72 \times 106$ with a mean of $4.97 \times 106 \mathrm{IU} / \mathrm{ml}$ and a median of $1.3 \times 106 \mathrm{IU} / \mathrm{ml}$. Twenty three patients $(18.11 \%)$ had low HCV RNA level<100 x103 IU/ml, 31 (24.41\%) had intermediate HCV RNA level $100 \times 103-1 \times 106 \mathrm{IU} / \mathrm{ml}$ and 73 (57.48\%) had a high HCV RNA level >1 x106 IU/ml.

Table (3) demonstrates that treatment regimen of DCV/SOF $+\mathrm{RBV}$ was received by most of the studied CHC patients; $70(55.12 \%)$. DCV+SOF were received by $47(37.01 \%)$, while only $10(7.87 \%)$ of the patients received SIM + SOF.

Table 4 showed that the mean AST, ALT, hemoglobin, total and direct bilirubin levels of the studied patients before treatment were $56.09 \pm 34.56 \mathrm{IU} / \mathrm{L}, 54.87 \pm 36.54 \mathrm{IU} / \mathrm{L}, 13.24 \pm$ $2.00 \mathrm{~g} / \mathrm{dL}, 0.89 \pm 0.53 \mathrm{mg} / \mathrm{dL}$ and $0.36 \pm 0.28 \mathrm{mg} / \mathrm{dL}$, respectively. After treatment their means were $32.15 \pm 9.54$ $\mathrm{IU} / \mathrm{L}, 33.79 \pm 10.73 \mathrm{IU} / \mathrm{L}, 10.89 \pm 1.78 \mathrm{~g} / \mathrm{dL}, 0.98 \pm 0.27 \mathrm{IU} / \mathrm{L}$ and $0.59 \pm 0.20 \mathrm{IU} / \mathrm{L}$, respectively. The means of the percentage change of the AST, ALT, hemoglobin, total and direct bilirubin levels after treatment were $-20.51 \pm 51.32 \%$, $12.83 \pm 60.13 \%,-16.87 \pm 13.19 \%, \quad 36.50 \pm 70.01 \%$ and $156.78 \pm 202.17 \%$, respectively (not shown in the table). There was a statistically significant decrease in ALT, AST and hemoglobin levels and a significant increase in direct bilirubin levels after treatment when compared with their levels before treatment. 
Table (1): Demographic and clinical data of the 127 chronic HCV patients.

Age (years)

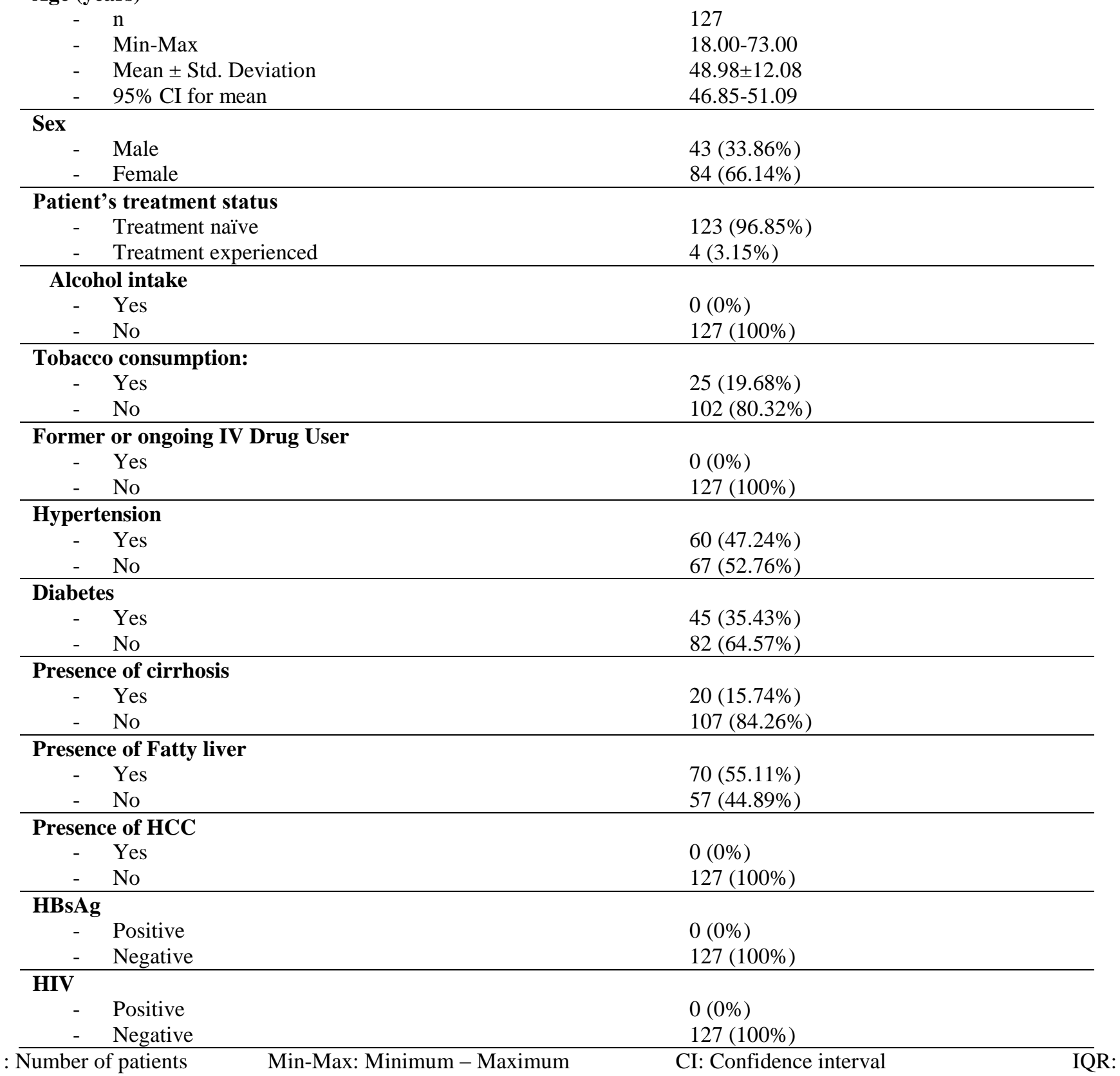

Inter-quartile range

Table (2): HCV RNA levels of the 127 chronic HCV patients before treatment

HCV RNA (Before treatment) (IU/ml)

\begin{tabular}{llll}
\hline & $\begin{array}{l}\text { Low } \\
\left(<100 \times 10^{3} \mathrm{IU} / \mathrm{ml}\right) \\
\mathrm{n}=23(18.11 \%)\end{array}$ & $\begin{array}{l}\text { Intermediate } \\
\left(100 \times 10^{3}-1 \times 10^{6} \mathrm{IU} / \mathrm{ml}\right) \\
\mathrm{n}=31(24.41 \%)\end{array}$ & $\begin{array}{l}\text { High } \\
\left(>1 \times 10^{6} \mathrm{IU} / \mathrm{ml}\right) \\
\mathrm{n}=73(57.48 \%)\end{array}$ \\
\hline Min - Max & $1.3 \times 10^{3}-73.00 \times 10^{3}$ & $0.14 \times 10^{6}-0.92 \times 10^{6}$ & $1.07 \times 10^{6}-72 \times 10^{6}$ \\
Mean \pm Std. Deviation & $25.88 \times 10^{3} \pm 21.85 \times 10^{3}$ & $0.44 \times 10^{6}-0.24 \times 10^{6}$ & $8.46 \times 10^{6} \pm 11.56 \times 10^{6}$ \\
\hline Mean \pm Std. Deviation & $4.97 \times 10^{6} \pm 9.6 \times 10^{6}$ & \\
\hline n: Number of patients & \multicolumn{2}{l}{ Min-Max: Minimum - Maximum }
\end{tabular}


Table (3): Treatment regimens received by the studied chronic HCV patients

\begin{tabular}{ll}
\hline Regimen & Number of patients \\
\hline DCV+SOF & $47(37.01 \%)$ \\
\hline DCV/SOF + RBV & $70(55.12 \%)$ \\
\hline SIM + SOF & $10(7.87 \%)$ \\
\hline
\end{tabular}

Table (4): AST, ALT, hemoglobin, total and direct bilirubin levels among the 127 chronic HCV patients before and after treatment

\begin{tabular}{|c|c|c|c|}
\hline & $\begin{array}{l}\text { Before treatment } \\
(n=127)\end{array}$ & $\begin{array}{l}\text { After treatment } \\
(n=127)\end{array}$ & Test of significance \\
\hline \multicolumn{3}{|l|}{ AST (IU/L) } & \multirow{4}{*}{$\begin{array}{l}\mathrm{t}_{(\mathrm{df}=126)}=7.527 \\
p=0.000^{*}\end{array}$} \\
\hline Min-Max & $15.00-165.00$ & $16.00-54.00$ & \\
\hline Mean \pm SD & $56.09 \pm 34.56$ & $32.15 \pm 9.54$ & \\
\hline $95 \%$ CI for mean & $50.02-62.16$ & $30.47-33.82$ & \\
\hline \multicolumn{3}{|l|}{ ALT (IU/L) } & \multirow{4}{*}{$\begin{array}{l}\mathrm{t}_{(\mathrm{df}=126)}=5.948 \\
p=0.000^{*}\end{array}$} \\
\hline Min-Max & $16.00-194.00$ & $17.00-64.00$ & \\
\hline Mean \pm SD & $54.87 \pm 36.54$ & $33.79 \pm 10.73$ & \\
\hline $95 \%$ CI for mean & $48.45-61.28$ & $31.90-35.67$ & \\
\hline \multicolumn{3}{|c|}{$\overline{\text { Hemoglobin }(\mathrm{g} / \mathrm{dL})}$} & \multirow{4}{*}{$\begin{array}{l}\mathrm{t}_{(\mathrm{df}=126)}=13.976 \\
p=0.000^{*}\end{array}$} \\
\hline Min-Max & $9.20-20.00$ & $7.60-14.00$ & \\
\hline Mean \pm SD & $13.24 \pm 2.00$ & $10.89 \pm 1.78$ & \\
\hline $95 \%$ CI for mean & $12.88-13.58$ & $10.57-11.20$ & \\
\hline \multicolumn{3}{|c|}{ Total bilirubin (mg/dL) } & \multirow{4}{*}{$\begin{array}{l}\mathrm{t}_{(\mathrm{df}=126)}=1.788 \\
p=0.076\end{array}$} \\
\hline Min-Max & $0.30-3.40$ & $0.60-2.40$ & \\
\hline Mean \pm SD & $0.89 \pm 0.53$ & $0.98 \pm 0.27$ & \\
\hline $95 \%$ CI for mean & $0.79-0.98$ & $0.93-1.03$ & \\
\hline \multicolumn{3}{|c|}{ Direct bilirubin(mg/dL) } & \multirow{4}{*}{$\begin{array}{l}\mathrm{t}_{(\mathrm{df}=126)}=7.827 \\
p=0.000 *\end{array}$} \\
\hline Min-Max & $0.10-1.60$ & $0.30-1.60$ & \\
\hline Mean \pm SD & $0.36 \pm 0.28$ & $0.59 \pm 0.20$ & \\
\hline $95 \%$ CI for mean & $0.30-0.40$ & $0.55-0.62$ & \\
\hline Number of patients & Min-Max: Minimuı & mum & rd Deviation \\
\hline
\end{tabular}

*: Statistically Significant $(\mathrm{p}<0.05)$

\section{DISCUSSION}

The objective of the current work was to evaluate DAAs in HCV treatment by investigating the SVR12 among patients with $\mathrm{CHC}$ infection. Treatment regimen preference was based on the available options at the time of initiation of therapy. There was no patient who died during treatment and there was no need to stop treatment with DAAs.

The regimens were well tolerated, with mostly mild adverse events that include headache, fatigue, insomnia, nausea, rash and anemia which are most typically associated with RBV therapy. Similar results were reported in other previous studies. $[27,28]$

The results of this study showed that all the patients except one had achieved the SVR12 (99.2\%). It was defined when HCV RNA was < 25 IU /ml. In accordance, El Raziky et al.,
(2017) [29] found that SMV plus SOF was associated with SVR in all 43 patients $(100 \%)$ treated for 12 weeks, including those with cirrhosis. Also, Feld et al., (2015)[30] found that velpatasvir - SOF led to SVR in all 116 patients $(100 \%)$ who were treated. Gragnani et al., (2016) [31] similarly reported $100 \%$ SVR12 by using different SOF-based antiviral combinations, confirming the very high antiviral efficacy of these drugs. Kohli et al., (2015) [32] found in a single-group trial of 21 patients that $95 \%$ who received 12 weeks of ledispavir-SOF achieved SVR. Abergel et al., (2016)[33] in a similar trial in France, found that 41 of 44 patients (93\%) treated for 12 weeks achieved SVR.

Regarding demographic data, the current study revealed that the median age of $\mathrm{HCV}$ infected patients was 51 years. In accordance, in Vallet et al., (2017) [27] study, it was 56 years 
and results revealed a very good response rate to DAAs (95\%). In contrast, Wahid et al., (2018)[34] aimed to determine the efficacy of DAAs in elderly people. They found that most of non-responders were older than 55 years of age. They concluded that treatment regimen of SOF + RBV had a limited effect on older patients, therefore practitioners and health care professionals need to reconsider treatment options for elderly populations.

In this study, eighty four (66.14\%) females received DAAs in comparison to $43(33.86 \%)$ males. Also, Lauletta et al., (2017)[28] reported that male/female ratio of patients enrolled in their study was 4:7. In contrast the patients in Vallet et al., (2017) [27] study were predominantly men $(58 \%)$.

In the current study, SVR12 was $100 \%$ in treatment naïve patients $(n=123,96.85 \%)$ and $75 \%(3 / 4)$, in treatment experienced. Regarding cirrhosis, SVR12 was $100 \%$ in cirrhotic patients and $99.1 \%(106 / 107)$, in non-cirrhotic patients. In several recent studies using different combinations of DAAs, a high efficiency SVR of $100 \%$ have been demonstrated in both treatment naïve and treatment experienced patients with genotype 4 infection. [35-37]

Among HCV patients enrolled in this study, there was a significant reduction of hemoglobin level in $\mathrm{HCV}$ patients after treatment $(\mathrm{p}=0.000)$. This may be explained by low nutritional status of the patients during the course of therapy and as a side effect of combination treatment of SOF and RBV. In agreement, Gayam et al., (2018)[38] found an association between DAAs administration and decreased hemoglobin level. Chang et al., (2017)[39] in their study on DAAs therapies for $\mathrm{CHC}$ among Asian Americans to evaluate SVR and adverse events, found that anemia was highest in patients receiving $\mathrm{SOF} / \mathrm{RBV}$. RBV induced a morphological change in the RBCs and inhibited their release from the bone marrow, leading to decrease in the lifespan of RBCs as well as reduced hemoglobin levels.[40,41]

In the current study, there was a significant decrease in AST and ALT levels in HCV patients after treatment when compared to values before treatment $(\mathrm{p}=0.000)$. This is an indication of efficacy of DAAs in viral clearance and reversing of liver dysfunction.[43] In agreement, Lauletta et al., (2017)[28] observed rapid and progressive reduction of ALT levels and reported that ALT levels were the biochemical parameters more significantly influenced by therapy. On the other hand, following viral eradication, Welsch et al., (2017)[43] found a high prevalence of elevated ALT levels after SVR, including patients that have been treated with new IFN-free DDA-based therapy. This finding confirms that the continuing elevation of aminotransferase upon SVR is not an unusual medical condition. Olveira et al., (2018) also found that some patients tend to have persistently elevated liver function test results after achieving an SVR and this was due to a liver disease rather than the given drug.[44] In the current study there was a significant increase in total and direct bilirubin levels among $\mathrm{HCV}$ patients after treatment when compared to their levels before treatment $(\mathrm{P}=0.000)$. In accordance to these findings, Bazeed et al., (2016)[45] found that there were bilirubin elevations and these elevations were not associated with transaminase elevations. Bilirubin elevations may be due to SOF which has an increasing effect on direct bilirubin causing cholestasis. Other reports revealed that oral therapy with RBV causes indirect hyperbilirubinemia where RBV causes a dose dependent red cell hemolysis after 2 to 3 weeks of therapy. The hemolysis is accompanied by a mild increase in indirect bilirubin, which may result in total bilirubin concentrations of 1.5 to $2.5 \mathrm{mg} / \mathrm{dL}$.[46,47] In contrast, Pietsch et al., (2018)[48] found a significant improvement in the aminotransferases as well as the liver function parameters of bilirubin and albumin. This is an indication of effectiveness of treatment in improvement of hepatic function.

Some all-oral, IFN-free DAAs combinations are now able to achieve a cure to $\mathrm{HCV}$ in over $90 \%$ of $\mathrm{HCV}$ patients after 12 weeks of treatment. [49] Further, IFN-free regimens will be available in the near future. Such new DAAs combinations need to show their added value in terms of bill cost, the length of treatment, RBV use, the drug-drug interaction profile and the safety/ tolerability profile in order to be competitive. A standard RBV-free tablet regimen with a low drug interaction profile and a good safety profile tend to be prerequisites as well as a shortened therapy period (6 or 8 weeks instead of 12 weeks). Patients who have failed previous treatment and developed resistance-associated variants (RAVS) to NS5A, should be rescued with potential combinations.[27]

\section{LIMITATIONS}

Measuring of RNA level was carried out 12 weeks following cessation of treatment only, so any relapse occurring afterword was not detected.

\section{RECOMMENDATIONS}

Responders to DAAs should be followed up at regular intervals in order not to miss any probable relapse. Health education programs for DAAs responders should be encouraged to avoid $\mathrm{HCV}$ reinfection. Future studies concerning non responders are recommended to uncover causes of non-responsiveness. Future studies are also recommended to evaluate other combinations of DAAs with high potency and non-overlapping resistance profiles and investigate treatments tailored to specific characteristics of the patient and the virus.

\section{REFERENCES}

1. Ramos H, Linares P, Badia E, Martin I, Gomez J, Almohalla $\mathrm{C}$, et al. Interferon-free treatments in patients with hepatitis $\mathrm{C}$ genotype 1-4 infections in a real-world setting. World J Gastrointest Pharmacol Ther. 2017;8(2):137-46.

2. Mohd Hanafiah K, Groeger J, Flaxman AD, Wiersma ST. Global epidemiology of hepatitis $C$ virus infection: new estimates of age-specific antibody to $\mathrm{HCV}$ seroprevalence. Hepatology. 2013;57(4):1333-42.

3. World Health Organization (WHO). Global hepatitis report 2017: World Health Organization; 2017. 
4. Amer FA, Gohar M, Yousef M. Epidemiology of hepatitis C virus infection in Egypt. Int J Trop Dis Health. 2015; 7(7):119-31.

5. Ministry of Health and Population /Egypt, El-Zanaty, Associates/Egypt, ICF International. Egypt Health Issues Survey 2015. Cairo, Egypt: Ministry of Health and Population/Egypt and ICF International; 2015.

6. Cuadros DF, Branscum AJ, Miller FD, Abu-Raddad LJ. Spatial epidemiology of hepatitis $C$ virus infection in Egypt: analyses and implications. Hepatology. 2014;60(4):1150-9.

7. Gower E, Estes C, Blach S, Razavi-Shearer K, Razavi H. Global epidemiology and genotype distribution of the hepatitis C virus infection. J Hepatol.2014;61(1 Suppl):S45-57.

8. Ruane PJ, Ain D, Stryker R, Meshrekey R, Soliman M, Wolfe PR, et al. Sofosbuvir plus ribavirin for the treatment of chronic genotype 4 hepatitis $\mathrm{C}$ virus infection in patients of Egyptian ancestry. J Hepatol. 2015;62(5):1040-6.

9. Ghany MG, Strader DB, Thomas DL, Seef LB. Diagnosis, management and treatment of hepatitis $\mathrm{C}$ : an update. Hepatology. 2009; 49(4):1335-74.

10. Lawitz E, Sulkowski MS, Ghalib R, Rodriguez-Torres M, Younossi ZM, Corregidor A, et al. Simeprevir plus sofosbuvir, with or without ribavirin, to treat chronic infection with hepatitis $\mathrm{C}$ virus genotype 1 in nonresponders to pegylated interferon and ribavirin and treatment-naive patients: the COSMOS randomised study. Lancet. 2014;384(9956):1756-65.

11. Alexopoulou A, Papatheodoridis GV. Current progress in the treatment of chronic hepatitis C. World J Gastroenterol. 2012;18(42):6060-9.

12. Kamal SM, El Tawil AA, Nakano T, He Q, Rasenack J, Hakam SA, et al. Peginterferon \{alpha\}-2b and ribavirin therapy in chronic hepatitis C genotype 4: impact of treatment duration and viral kinetics on sustained virological response. Gut. 2005;54(6):858-66.

13. Lam BP, Jeffers T, Younoszai Z, Fazel Y, Younossi ZM. The changing landscape of hepatitis $\mathrm{C}$ virus therapy: focus on interferon-free treatment. Therap Adv Gastroenterol. 2015;8(5):298-312.

14. Kohli A, Shaffer A, Sherman A, Kottilil S. Treatment of hepatitis C: a systematic review. JAMA. 2014;312(6):631-40.

15. Jakobsen JC, Nielsen EE, Koretz RL, Gluud C. Do direct acting antivirals cure chronic hepatitis C? BMJ. 2018;361:k1382.

16. Esmat G, El Kassas M, Hassany M, Gamil M, El Raziky M. Optimizing treatment for HCV genotype 4: PEG-IFN alfa $2 \mathrm{a}$ vs. PEG-IFN alfa $2 \mathrm{~b}$; the debate continues. Liver Intern. 2014;34 Suppl 1:24-8.

17. Elgharably A, Gomaa AI, Crossey MM, Norsworthy PJ, Waked I, Taylor-Robinson SD. Hepatitis C in Egypt-past, present, and future. Int J Gen Med. 2017;10:1.

18. Wanis H. Hepatitis C treatment in Egypt: Why cost remains a challenge. Egyptian Initiative for Personal Rights: Economic and Social Justice Unit; 2014. available from: https://eipr.org/sites/default/files/reports/pdf/hcv_treatme nt_in_egypt.pdf [Accessed in: Jan, 2019]

19. Wedemeyer H, Duberg AS, Buti M, Rosenberg WM, Frankova S, Esmat G, et al. Strategies to manage hepatitis C virus (HCV) disease burden. J Viral Hepat. 2014; 21 Suppl 1:60-89.

20. Cholongitas E, Papatheodoridis GV. Sofosbuvir: a novel oral agent for chronic hepatitis C. Ann Gastroenterol. 2014;27(4):331-7.

21. Daniel WW, Cross CL. Biostatistics: a foundation for analysis in the health sciences. Pheladelphia: Wiley \& Sons; 2018.

22. Faul F, Erdfelder E, Lang AG, Buchner A. G*Power 3: a flexible statistical power analysis program for the social, behavioral, and biomedical sciences. Behav Res Methods. 2007;39(2):175-91.

23. Lewis S, Bain B, Bates ID. Lewis practical haematology. Churchill Livingstone New York. 2001.

24. Burtis CA, Ashwood ER, Bruns DE. Tietz textbook of clinical chemistry and molecular diagnostics-e-book: Elsevier Health Sciences; 2012.

25. Wong ML, Medrano JF. Real-time PCR for mRNA quantitation. Biotechniques. 2005;39(1):75-85.

26. IBM Corp. IBM SPSS Statistics for Windows, Version 21.0. Armonk, NY: IBM Corp.; Released 2012.

27. Vallet-Pichard A, Pol S. Grazoprevir/elbasvir combination therapy for HCV infection. Therap Adv Gastroenterol. 2017;10(1):155-67.

28. Lauletta G, Russi S, Pavone F, Vacca A, Dammacco F. Direct-acting antiviral agents in the therapy of hepatitis $\mathrm{C}$ virus-related mixed cryoglobulinaemia: a single-centre experience. Arthritis Res Ther. 2017;19(1):74.

29. El Raziky M, Gamil M, Ashour M, Sameea EA, Doss W, Hamada Y, et al. Simeprevir plus sofosbuvir for eight or 12 weeks in treatment-naïve and treatment-experienced hepatitis $\mathrm{C}$ virus genotype 4 patients with or without cirrhosis. J Viral Hepat. 2017;24(2):102-10.

30. Feld JJ, Jacobson IM, Hézode C, Asselah T, Ruane PJ, Gruener N, et al. Sofosbuvir and velpatasvir for $\mathrm{HCV}$ genotype 1, 2, 4, 5, and 6 infection. $\mathrm{N}$ Engl $\mathrm{J}$ Med. 2015;373(27):2599-607.

31. Gragnani L, Visentini M, Fognani E, Urraro T, De Santis A, Petraccia L, et al. Prospective study of guidelinetailored therapy with direct-acting antivirals for hepatitis $\mathrm{C}$ virus-associated mixed cryoglobulinemia. Hepatology. 2016;64(5):1473-82.

32. Kohli A, Kapoor R, Sims Z, Nelson A, Sidharthan S, Lam $\mathrm{B}$, et al. Ledipasvir and sofosbuvir for hepatitis C genotype 4: a proof-of-concept, single-centre, open-label phase 2a cohort study. Lancet Infect Dis. 2015;15(9):1049-54.

33. Abergel A, Metivier S, Samuel D, Jiang D, Kersey K, Pang PS, et al. Ledipasvir plus sofosbuvir for 12 weeks in patients with hepatitis C genotype 4 infection. Hepatology. 2016;64(4):1049-56.

34. Wahid B, Waqar M, Saleem K, Shafi F, Rehman Z, Hanif $\mathrm{I}$, et al. Poor response to direct-acting antiviral therapy in HCV-infected elderly population: a real-life cohort study 
based on GeneXpert ${ }^{\circledR}$ technology. Future Virol. 2018;13(7):467-74.

35. Hézode C, Asselah T, Reddy KR, Hassanein T, Berenguer $\mathrm{M}$, Fleischer-Stepniewska $\mathrm{K}$, et al. Ombitasvir plus paritaprevir plus ritonavir with or without ribavirin in treatment-naive and treatment-experienced patients with genotype 4 chronic hepatitis $\mathrm{C}$ virus infection (PEARL-I): a randomised, open-label trial. Lancet. 2015;385(9986):2502-9.

36. Kwo P, Gane EJ, Peng C-Y, Pearlman B, Vierling JM, Serfaty L, et al. Effectiveness of elbasvir and grazoprevir combination, with or without ribavirin, for treatmentexperienced patients with chronic hepatitis $\mathrm{C}$ infection. Gastroenterology. 2017;152(1):164-75.

37. Di Biagio A, Taramasso L, Cenderello G. Treatment of hepatitis $\mathrm{C}$ virus genotype 4 in the DAA era. Virol J. 2018;15(1):180.

38. Gayam V, Mandal AK, Khalid M, Mukhtar O, Gill A, Garlapati P, et al. Association between vitamin D levels and treatment response to direct-acting antivirals in chronic hepatitis C: A real-world study. Gastroenterology Res. 2018;11(4):309-16.

39. Chang CY, Nguyen P, Le A, Zhao C, Ahmed A, Daugherty $\mathrm{T}$, et al. Real-world experience with interferon-free, direct acting antiviral therapies in Asian Americans with chronic hepatitis $\mathrm{C}$ and advanced liver disease. Medicine. 2017;96(6): e6128.

40. Homma M, Hosono H, Hasegawa Y, Kohda Y. Morphological transformation and phosphatidylserine exposure in erythrocytes treated with ribavirin. Biol Pharm Bull. 2009;32(11):1940-2.

41. Ronzoni L, Aghemo A, Rumi M, Prati G, Colancecco A, Porretti L, et al. Ribavirin suppresses erythroid differentiation and proliferation in chronic hepatitis $\mathrm{C}$ patients. J Viral Hepat. 2014;21(6):416-23.

42. Van der Meer AJ, Berenguer M. Reversion of disease manifestations after HCV eradication. J Hepatol. 2016;65(1):S95-S108.

43. Welsch C, Efinger M, von Wagner M, Herrmann E, Zeuzem S, Welzel TM, et al. Ongoing liver inflammation in patients with chronic hepatitis $\mathrm{C}$ and sustained virological response. PLoS One. 2017;12(2):e0171755.

44. Olveira A, Domínguez L, Troya J, Arias A, Pulido F, Ryan P, et al. Persistently altered liver test results in hepatitis $\mathrm{C}$ patients after sustained virological response with direct-acting antivirals. J Viral Hepat. 2018;25(7):818-24.

45. Bazeed FB, Elsayed EH, Abd El-Aziz AA. Evaluation of serum aminotransaminases and bilirubin in different treatment regimens for chronic hepatitis $\mathrm{C}$ virus. JPBS. 2016;11(4):20-6.

46. Zimmerman HJ. Hepatotoxicity: the adverse effects of drugs and other chemicals on the liver. New York: Lippincott Williams \& Wilkins; 1999.

47. Kamar N, Rostaing L, Abravanel F, Garrouste C, Lhomme S, Esposito L, et al. Ribavirin therapy inhibits viral replication on patients with chronic hepatitis eqdirus infection. Gastroenterology. 2010;139(5):1612-8.

48. Pietsch V, Deterding K, Attia D, Ringe KI, Heidrich B, Cornberg M, et al. Long-term changes in liver elasticity in hepatitis $\mathrm{C}$ virus-infected patients with sustained virologic response after treatment with direct-acting antivirals. United European Gastroenterol J. 2018;6(8):1188-98.

49. Zhang J, Nguyen D, Hu K-Q. Chronic hepatitis C virus infection: a review of current direct-acting antiviral treatment strategies. N Am J Med Sci. 2016;9(2):47-54. 